\title{
COASTAL EROSION HAZARD AND VULNERABILITY: CASE STUDY OF PORTICELLO, SOUTH CALABRIA, ITALY
}

\author{
GIUSEPPINA CHIARA BARILLÀ ${ }^{1}$, GIUSEPPE BARBARO ${ }^{1}$, GIANDOMENICO FOTI ${ }^{1}$, \\ PIERLUIGI MANCUSO ${ }^{2}$, VINCENZO FIAMMA ${ }^{1}$, AGNIESZKA MALESINSKA $^{3}$, \\ PIERFABRIZIO PUNTORIERI ${ }^{1}$ \& MARIA MANDALARI ${ }^{1}$ \\ ${ }^{1}$ DICEAM Department, Mediterranea University of Reggio Calabria, Italy \\ ${ }^{2}$ Public Works Department of Calabria Region, Italy \\ ${ }^{3}$ Faculty of Building Services, Hydro and Environmental Engineering, Warsaw University of Technology, Poland
}

\begin{abstract}
Coastal erosion is due to natural phenomena and anthropogenic interventions that alter the coastal dynamics and the sediment balance. Therefore, to manage the coastal areas and to correctly design the necessary defence interventions, it is necessary to analyze all these factors. Consequently, in recent years the methodologies for the coastal erosion hazard and vulnerability assessment have increasing importance. However, there is currently a lack of a general methodology that considers all the factors that influence the coastal dynamics and, therefore, the hazard and the vulnerability. This paper, through a case study, describes a new methodology based on indices that considers all the factors that influence the hazard and the vulnerability, thus resulting in general validity. This methodology defines two indices of hazard and vulnerability. The hazard index considers all the natural processes that contribute to the phenomenon of coastal erosion, such as tides, currents, average sea level rise due to climate change, wave climate and both coastal and river sediment transport. The vulnerability index, on the other hand, includes all those characteristics of the coast that can make it more or less vulnerable to coastal erosion, such as its geological and morphological characteristics (both of the emerged and submerged part), its evolutionary trend, the presence of dune systems, vegetation and coastal and/or port defence works, the subsidence rates and the degree of waterproofing of the coast. The case study concerns Porticello, a town near the Strait of Messina characterized by a high coastal erosion risk. Porticello represents an interesting case study due to the peculiarities of the Strait of Messina and the presence of numerous coastal structures. The study area extends for about $1.5 \mathrm{~km}$, inside there are numerous coastal structures, two river mouths and numerous houses built close to the shoreline.

Keywords: coastal erosion, coastal erosion risk assessment, hazard, vulnerability, index-based methodology, coastal structures.
\end{abstract}

\section{INTRODUCTION}

Coastal areas are particularly important from a socio-economic point of view. Indeed, about $20 \%$ of the world population lives within $25 \mathrm{~km}$ of the coast [1] and the number of coastal cities has quintupled in the last 70 years [2]. This anthropogenic pressure has often altered the coastal dynamics and the sedimentary regime, triggering erosive processes [3]. Indeed, most of the world's coastal areas are currently subject to coastal erosion [4].

Along with anthropogenic pressure, various natural factors can also alter coastal dynamics by triggering erosive processes [5], [6]. The main natural factors are the wave climate [7][10] and the sedimentary balance between longshore and river transport [11]-[17]. Regarding the anthropogenic pressure, it can concern both rivers and coasts. In the river area it is mainly the construction of dams and weirs, the sediment withdrawal, and the subsidence [18]-[23]. In the coastal areas it is mainly the construction of port and coastal structures [24]-[26].

Furthermore, due to anthropogenic pressure there is an increase in the vulnerability of coastal areas to the action of floods and sea storms [27]-[29], especially in case of concurrent events [30]-[32]. The frequency and the intensity of these events can be increased by climate 
change, which also have consequences on sea level rise and, therefore, on erosive processes [33], [34].

Therefore, to effectively manage coastal areas it is necessary to monitor the above factors and the shoreline changes caused by the alteration of the sedimentary regime [35]-[38].

In recent years, the methodologies for the coastal erosion hazard and vulnerability assessment have increasing importance [39]-[43]. These methodologies allow to effectively manage the risk areas by allocating the funds intended for coastal protection with a certain order of priority [44], [45].

The Italian and international panorama is characterized not only by different evaluation methodologies, variables between the different coastal regions, but above all by a great variety and dispersion of factors taken into consideration by these different methodologies [46]-[49]. Therefore, there is currently a lack of a general methodology that considers all the factors that influence the coastal dynamics and, therefore, the hazard and the vulnerability.

Among the existing methods, the index-based methods are the simplest and most widely used [50]. They are based on a quantitative or semi-quantitative evaluation of different variables or indicators which are combined with each other, through an appropriate set of weights, obtaining as a result an overall index, the coastal vulnerability index (CVI) [51], [52]. In addition, these methods can be supported by GIS applications, therefore it is possible to produce maps that allow to describe the spatial distribution of the CVI index and to overlap these results with additional spatial information [53].

This paper, through a case study, describes a new methodology based on indices that considers all the factors that influence the hazard and the vulnerability, thus resulting in general validity. The case study concerns Porticello, a town near the Strait of Messina which represents an interesting case study due to the peculiarities of the Strait of Messina and the presence of numerous coastal structures. The study area extends for about $1.5 \mathrm{~km}$, inside there are numerous coastal structures, two river mouths and numerous houses built close to the shoreline.

\section{SITE DESCRIPTION}

The town of Porticello is a fraction of the city of Villa San Giovanni, on the Tyrrhenian side of Calabria. In particular, the study area is located in the terminal part of the Strait of Messina, a portion of the sea that connects the Ionian Sea with the Tyrrhenian one and which, separating the two cities of Messina and Reggio Calabria with their respective urban areas, it separates Sicily from Calabria and therefore from peninsular Italy and the continent. Due to its morphological characteristics, the Strait can be represented as an inverted funnel, reaching, at its narrowest point, a width of about $3 \mathrm{~km}$ : at this point there is an underwater saddle, with a minimum depth of about $80 \mathrm{~m}$, which divides the whole area into two subbasins with different characteristics; to the north of the saddle (Tyrrhenian Sea), in fact, the depths gradually increase, unlike the southern part (Ionian Sea) where the seabed becomes deeper very quickly. Furthermore, the Strait of Messina is the meeting point between two seas with different characteristics in terms of salinity and temperature. All this means that the Strait is home to very strong currents, so much so that in ancient times the legends told of the presence of two monsters (Scylla and Cariddi) that ravaged the navigation between Calabria and Sicily (Fig. 1).

The coast in question is located between Punta Pezzo and Torre Cavallo (Fig. 2(a)), more precisely from the Zagarella river to the Commenda Divale river. The stretch considered has a length of about $1,500 \mathrm{~m}$ and is highlighted in red in the Fig. 2(b). The study area is characterized by a high risk of coastal erosion, as numerous houses are built close to the state- 


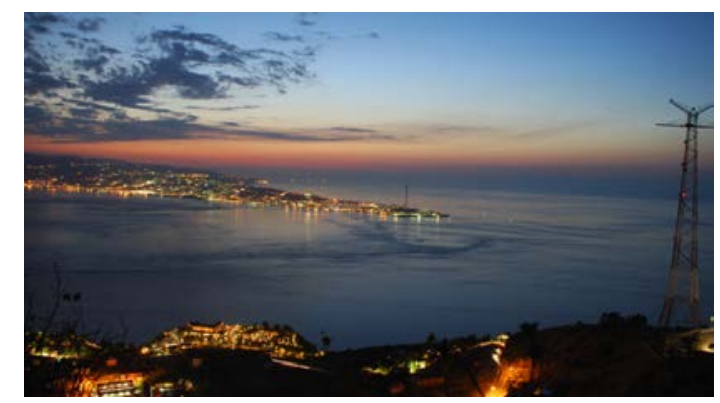

Figure 1: The area of the Strait of Messina with its currents.
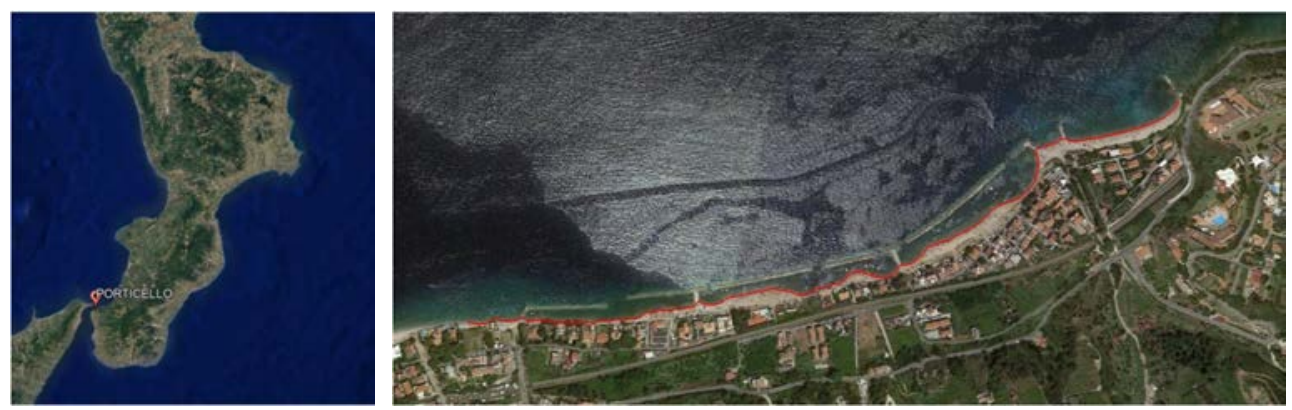

Figure 2: The study area. Location of Porticello on the left. Detail of the examined area on the right; the stretch of coast studied highlighted in red.

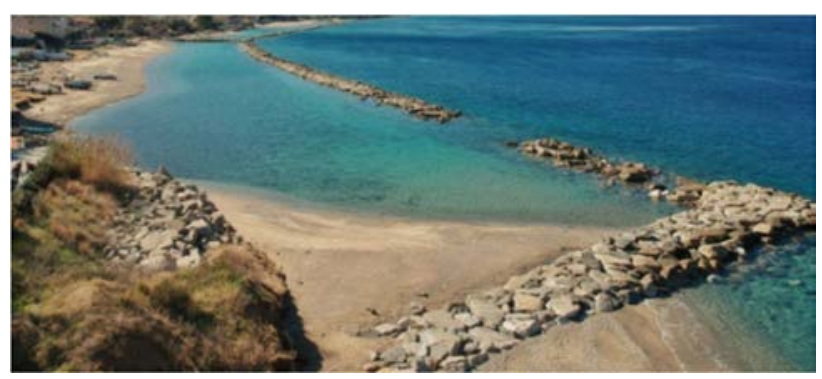

Figure 3: The coastal defence works completed in 2015.

owned area and in some places, the beach is almost non-existent, so much so that in 2015 coastal defence works were completed (Fig. 3). In addition, in the study area, there are several mouths of valleys and the Santa Trada river.

\section{METHODOLOGY}

The new methodology proposed therefore arises from the consideration that in the literature there is no risk assessment method that considers all the main factors that influence coastal hazard and vulnerability, thus determining a risk index. For its simplicity of application and for the easy visualization of the results obtained on GIS, a methodology based on indices was 
chosen, applicable on a regional scale, and which is valid for any Italian region, or which can consider all the factors that influence coastal dynamics.

New indices of coastal hazard and vulnerability were therefore defined, functional to the determination of a standardized coastal risk assessment procedure. For this purpose, the Calabria region, which represents a complex case study for the application of the elaborated procedure, has been divided into three macro-areas according to the different exposure of the coasts to wave motion: the Tyrrhenian area, the area of the Strait of Messina and the Ionian area, characterized not only by different climatic characteristics, above all by different geographical characteristics, in particular in terms of fetch.

All the indices of hazard and vulnerability, appropriately determined, have been classified on a scale from 1 to 5 . In particular, based on the level of hazard/vulnerability, with 1 corresponding to a "very low" grade, with 5 corresponding to a "very high" grade. The hazard/vulnerability classes have been effectively calibrated according to the indices considered. With the exception of the factors defined in a range of values already between 0 and 1 (such as, for example, those relating to the wave climate, coastal and river sediment transport, etc.), a score will be assigned for all other factors between 0 and 1 , depending on the hazard/vulnerability class resulting from the assessment; in particular, the vulnerability factors that may not come into play in a specific location (such as, for example, the presence of dune systems, port works, the phenomenon of subsidence, etc.) will be assigned a value of 0 , without compromising the structure of the overall index.

The overall hazard/vulnerability index can therefore be evaluated using the following equation:

$$
I=\sqrt{\frac{v_{1}^{2}+v_{2}^{2}+v_{3}^{2}+\cdots+v_{n}^{2}}{n}},
$$

where $v_{1}, v_{2}, v_{3}, \ldots, v_{n}$ represent all the indices of hazard/vulnerability described below and evaluated as reported in Table 1 .

Table 1: Hazard/vulnerability classes and assigned score.

\begin{tabular}{|l|c|c|c|c|c|}
\hline Number of classes & 1 & 2 & 3 & 4 & 5 \\
\hline Classification & Very low & Low & Moderate & High & Very high \\
\hline Score awarded & 0.2 & 0.4 & 0.6 & 0.8 & 1 \\
\hline
\end{tabular}

\subsection{Indices of hazard}

The hazard indices are representative of the factors that strongly affect the coastal erosion process, such as tides, currents, average sea level rise due to climate change, wave offshore climate and both coastal and fluvial sediment transport.

As regards the index linked to the variation of the mean sea level (SLR), the classification proposed by Pendleton et al. [54] who conducted a study on the coastal vulnerability linked to the rise in the mean sea level, was adopted.

The index that considers the tide range was defined considering the classification proposed by Davies [55].

The index connected to marine currents was classified according to the average current values of the Italian seas and the Strait of Messina; in fact, in the area of the Strait of Messina the currents, due to the conformation of the Calabrian and Sicilian coasts, take on much higher values than those of the Mediterranean Sea. 
The wave climate index was determined by considering a weighted average, with equal weights, of four sub-indices, which take values between 0 and 1, thus defined:

1. Index associated to the flow of energy: it takes into account the energy contribution of the sea states incident on the coast.

2. Index related to the maximum energy flux direction: it takes into account the sectors from which the strongest waves come, as a coast subject to orthogonal sea states is more stressed than inclined sea states.

3. Index linked to the change in significant height with the return period, determined using the Boccotti methodology [56].

4. Index connected to the variation of the run-up with the return period, determined using the model of Stockdon et al. [57].

The index related to coastal sediment transport varies between 0 and 1 , as it has been defined as the ratio between the annual average longshore solid material flow and its maximum value calculated in the reference macro-area. Longshore sediment transport was evaluated based on the model of Tomasicchio et al. [58].

The index linked to river sediment transport was defined in a similar way to that linked to coastal sediment transport, therefore it also varies between 0 and 1 . It was decided to use the Gavrilovic model [59]: it is a multiparametric empirical model and it is particularly useful for quantifying the solid transport caused by the soil erosion by water (WSE). WSE is very important in territories such as Calabria, characterized by basins with high slopes and irregular hydrological regimes, with alternation between dry periods and sudden flood events.

\subsection{Indices of vulnerability}

The vulnerability indices allow to describe the degree of susceptibility of the territory to the phenomenon of coastal erosion: for this reason it is essential to evaluate the evolutionary trend of the coast (in the recent, short, medium, long and very long term), the geological and morphological characteristics of the coast (both of the emerged part that of the submerged part), the presence of dune systems, vegetation and coastal and/or port defence works, the subsidence rates of the ground and the degree of waterproofing of the coast.

As regards the index connected to the type of coast, the determination of the vulnerability classes was carried out using the classification proposed by Silva et al. [60], as it is complete and in line with the types of coasts present in Calabria.

The index relating to the morphology of the emerged coast was determined as the average of two sub-indices:

1. Index linked to the slope of the beach, whose classification was based on the slope characteristics of all the coasts of Calabria.

2. Index related to the average width of the emerged beach, whose classification was made according to the maximum value of the average width of the Calabrian beaches.

The index linked to the characteristics of the submerged part of the coast was determined as the average of the following two sub-indices:

1. Index associated to the slope of the seabed, classified in a similar way to that related to the slope of the beach.

2. Index connected to the sedimentology of the seabed, classified according to the various types of sand that can make up the seabed. 
The index that identifies the evolutionary trend of the shoreline is very important because it is indicative of the state of health of a coast. This index is based on the estimate of the average shoreline variation rate, $\mathrm{v}$ expressed in $\mathrm{m} / \mathrm{year}$, according to which it has been classified into 5 classes: one for the advancement $(\mathrm{v}>0.5)$, one for the stability $(-0.5 \leq \mathrm{v} \leq$ $0.5)$, one for erosion $(-1 \leq \mathrm{v}<-0.5)$, one for intense erosion $(-2 \leq \mathrm{v}<-1)$, and one for severe erosion $(\mathrm{v}<-2)$. This evaluation of the evolutionary trend of the shoreline was carried out for different time intervals: the two most recent available shorelines; a short-term evolutionary trend, with reference to the shorelines available in the last 5 years; a mediumterm evolutionary trend, with reference to the shorelines available in the last 20 years; a longterm evolutionary trend, with reference to the shorelines available in the last 30 years; a very long-term evolutionary trend, with reference to the shorelines available in the past 70 years. The index associated with the evolutionary trend of the coast was therefore defined as the weighted average of the various trends referred to the different time intervals considered, with increasing weight as the time interval increases.

The index associated to the subsidence of the land was classified according to the range of variability of the subsidence rates, resulting from studies conducted for the Calabria region.

The index related to the presence of dune systems was evaluated according to the morphological characteristics of the dunes (height and width, considered orthogonally to the coastline) and according to the percentage of the shoreline characterized by the presence of these systems, fundamental for the natural nourishment of the beaches, subject to the action of the storms.

The vegetation index considers both the vegetation present on the beach (in terms of its width behind the beach and the percentage of the coastline characterized by the presence of vegetation), useful for dissipating the energy of the wave motion and reducing erosion in the case of extreme events, and that present in the seabed, which is represented in the Mediterranean basin largely by Posidonia oceanica (Boolean: presence/absence).

The index linked to the presence of port works considers the interruption that such a structure determines in the natural dynamics of the sediments, generating areas of advancement of the coast and areas of retreat.

The index related to the presence of coastal defence works is evaluated according to the ratio between the total length of the protected coast and the length of the stretch of coast considered, thus obtaining the percentage of coverage of the coast by this structure. It is also possible to consider, in defining the index, the degree of conservation of the structures, as a damaged barrier will certainly not perform the same degree of protection as a newly built barrier. Consequently, it is possible to multiply the value of the index by a corrective factor, significant of the state of conservation of the structures, before proceeding to determine the corresponding vulnerability class.

Finally, similarly to how the previous index was defined, it was possible to define an index linked to the portion of the anthropized or cemented coastline, expressed as a percentage, where the coastline is not identified by the shoreline, but by the presence of a structure or infrastructure, often protected by grazing structures.

\section{RESULTS AND DISCUSSION}

The results of applying the methodology described above in the Porticello area are shown briefly in the following tables (Tables 2-6) which report all the hazard and vulnerability factors relating to the location in question, the evaluation of which appears highlighted. Note how the factors relating to dune systems, ground subsidence and the presence of port works 
Table 2: Assessment of the hazard variables.

\begin{tabular}{|l|c|c|c|c|c|}
\hline \multirow{2}{*}{ Hazard variables } & \multicolumn{5}{|c|}{ Hazard classes } \\
\cline { 2 - 6 } & Very low & Low & Moderate & High & Very high \\
& 1 & 2 & 3 & 4 & 5 \\
\hline SLR (mm/year) & $<1.8$ & $1.8-2.5$ & $2.5-3.0$ & $3.0-3.4$ & $>3.4$ \\
\hline Mean tidal excursion (m) & $<1$ & $1-2$ & $2-4$ & $4-6$ & $>6$ \\
\hline Sea currents (knots) & $<0.5$ & $0.5-1.5$ & $1.5-3$ & $3-5$ & $>5$ \\
\hline Wave climate & $<0.2$ & $0.2-0.4$ & $0.4-0.6$ & $0.6-0.8$ & $>0.8$ \\
\hline Coastal sediment transport & $<0.2$ & $0.2-0.4$ & $0.4-0.6$ & $0.6-0.8$ & $>0.8$ \\
\hline River sediment transport & $>0.8$ & $0.8-0.6$ & $0.6-0.4$ & $0.4-0.2$ & $<0.2$ \\
\hline
\end{tabular}

Table 3: Evaluation of the wave climate index.

\begin{tabular}{|l|c|c|c|c|c|}
\hline \multirow{2}{*}{ Wave climate index } & \multicolumn{5}{|c|}{ Hazard classes } \\
\cline { 2 - 6 } & Very low & Low & Moderate & High & Very high \\
\hline Total energy flux & $<0.2$ & $0.2-0.4$ & $0.4-0.6$ & $0.6-0.8$ & $>0.8$ \\
\hline $\begin{array}{l}\text { Maximum energy flux } \\
\text { direction }\end{array}$ & $<0.2$ & $0.2-0.4$ & $0.4-0.6$ & $0.6-0.8$ & $>0.8$ \\
\hline $\begin{array}{l}\text { Variation of significant } \\
\text { height with return period }\end{array}$ & $<0.2$ & $0.2-0.4$ & $0.4-0.6$ & $0.6-0.8$ & $>0.8$ \\
\hline $\begin{array}{l}\text { Variation of run-up with } \\
\text { return period }\end{array}$ & $<0.2$ & $0.2-0.4$ & $0.4-0.6$ & $0.6-0.8$ & $>0.8$ \\
\hline
\end{tabular}

Table 4: Assessment of the vulnerability variables.

\begin{tabular}{|c|c|c|c|c|c|}
\hline \multirow{2}{*}{$\begin{array}{l}\text { Vulnerability } \\
\text { variables }\end{array}$} & \multicolumn{5}{|c|}{ Vulnerability classes } \\
\hline & $\begin{array}{c}\text { Very low } \\
1\end{array}$ & $\begin{array}{c}\text { Low } \\
2\end{array}$ & $\begin{array}{c}\text { Moderate } \\
3 \\
\end{array}$ & $\begin{array}{c}\text { High } \\
4\end{array}$ & $\begin{array}{l}\text { Very high } \\
5\end{array}$ \\
\hline Type of coast & $\begin{array}{l}\text { Rocky, } \\
\text { cliffed } \\
\text { coast }\end{array}$ & $\begin{array}{l}\text { Medium } \\
\text { cliffs, } \\
\text { indented } \\
\text { coast }\end{array}$ & $\begin{array}{l}\text { Low cliffs, } \\
\text { alluvional } \\
\text { plains }\end{array}$ & $\begin{array}{l}\text { Cobble } \\
\text { beaches, } \\
\text { estuary, } \\
\text { lagoon }\end{array}$ & $\begin{array}{c}\text { Sand } \\
\text { beach, } \\
\text { dunes } \\
\text { system }\end{array}$ \\
\hline $\begin{array}{l}\text { Emerged coast } \\
\text { morphology }\end{array}$ & 0.2 & $0.2-0.4$ & $0.4-0.6$ & $0.6-0.8$ & $>0.8$ \\
\hline $\begin{array}{l}\text { Submerged } \\
\text { coast } \\
\text { morphology }\end{array}$ & 0.2 & $0.2-0.4$ & $0.4-0.6$ & $0.6-0.8$ & $>0.8$ \\
\hline $\begin{array}{l}\text { Evolutionary } \\
\text { trend of } \\
\text { shoreline } \\
\text { (m/year) }\end{array}$ & $>0.5$ & 0.5 to -0.5 & -0.5 to -1.0 & -1.0 to -2.0 & $>-2.0$ \\
\hline Vegetation & \multicolumn{5}{|c|}{ Presence of Posidonia Oceanica (0.5) } \\
\hline $\begin{array}{l}\text { Coastal } \\
\text { defence works }\end{array}$ & $>0.8$ & $0.8-0.6$ & $0.6-0.4$ & $0.4-0.2$ & $<0.2$ \\
\hline $\begin{array}{l}\text { Degree of } \\
\text { anthropization } \\
\text { of the coast }\end{array}$ & $<0.2$ & $0.2-0.4$ & $0.4-0.6$ & $0.6-0.8$ & $>0.8$ \\
\hline
\end{tabular}


Table 5: Evaluation of the coastal morphology indices.

\begin{tabular}{|l|l|c|c|c|c|c|}
\hline \multirow{2}{*}{ Coastal morphology indices } & \multicolumn{5}{|c|}{ Vulnerability classes } \\
\cline { 3 - 7 } & $\begin{array}{c}\text { Very } \\
\text { low }\end{array}$ & Low & Moderate & High & $\begin{array}{c}\text { Very } \\
\text { high }\end{array}$ \\
\hline \multirow{2}{*}{$\begin{array}{l}\text { Emerged } \\
\text { part }\end{array}$} & Beach slope (\%) & $>12$ & $12-9$ & $9-6$ & $6-3$ & $<3$ \\
\cline { 2 - 7 } & $\begin{array}{l}\text { Average width of the } \\
\text { beach (m) }\end{array}$ & $>80$ & $80-60$ & $60-40$ & $40-20$ & $<20$ \\
\hline \multirow{2}{*}{$\begin{array}{l}\text { Submerged } \\
\text { part }\end{array}$} & Seabed slope (\%) & $<2$ & $2-6$ & $6-10$ & $10-20$ & $>20$ \\
\cline { 2 - 7 } & $\begin{array}{l}\text { Seabed } \\
\text { sedimentology }\end{array}$ & $\begin{array}{c}\text { Very } \\
\text { coarse } \\
\text { sand }\end{array}$ & $\begin{array}{c}\text { Coarse } \\
\text { sand }\end{array}$ & $\begin{array}{c}\text { Medium } \\
\text { sand }\end{array}$ & $\begin{array}{c}\text { Fine } \\
\text { sand }\end{array}$ & $\begin{array}{c}\text { Very } \\
\text { fine } \\
\text { sand }\end{array}$ \\
\hline
\end{tabular}

Table 6: Evaluation of the evolutionary trend of the shoreline indices.

\begin{tabular}{|l|c|c|c|c|c|}
\hline \multirow{2}{*}{$\begin{array}{l}\text { Evolutionary trend of } \\
\text { the shoreline indices }\end{array}$} & $\begin{array}{c}\text { Very } \\
\text { low }\end{array}$ & Low & Moderate & High & $\begin{array}{l}\text { Very } \\
\text { high }\end{array}$ \\
\hline Most recent (m/year) & $>0.5$ & 0.5 to -0.5 & -0.5 to -1.0 & -1.0 to -2.0 & $>-2.0$ \\
\hline Short-term (m/year) & $>0.5$ & 0.5 to -0.5 & -0.5 to -1.0 & -1.0 to -2.0 & $>-2.0$ \\
\hline $\begin{array}{l}\text { Middle-term } \\
\text { (m/year) }\end{array}$ & $>0.5$ & 0.5 to -0.5 & -0.5 to -1.0 & -1.0 to -2.0 & $>-2.0$ \\
\hline Long-term (m/year) & $>0.5$ & 0.5 to -0.5 & -0.5 to -1.0 & -1.0 to -2.0 & $>-2.0$ \\
\hline $\begin{array}{l}\text { Very long-term } \\
\text { (m/year) }\end{array}$ & $>0.5$ & 0.5 to -0.5 & -0.5 to -1.0 & -1.0 to -2.0 & $>-2.0$ \\
\hline
\end{tabular}

are not present in the tables, as they do not characterize the study area. These variables have been assigned a zero value in the application of the eqn (1).

As regards for the tide variations, in the Messina Strait area, the excursion is modest (0.2$0.3 \mathrm{~m}$ ), as obtained from the analysis of the historical series of the tide gauge located in the cities of Reggio Calabria and Messina. It has been estimated that in the studied area the currents have a value of about 3-4 knots, while in the Tyrrhenian and Ionian they vary between 0.4 and 0.7 knots. The wave climate was analysed starting from the data obtained by applying the ABRC-MACRO software, developed by HR Wallingford Ltd. All the vulnerability characteristics analysed were obtained from various cartography data, which consists of historical shorelines taken from the Calabrian Geoportal, orthophotos taken from the National Geoportal and satellite imagery from 2015 to today provided by Google Earth.

Finally, the overall hazard index is equal to 0.69 , while the vulnerability index is equal to 0.50 .

\section{CONCLUSIONS}

In territories such as Calabria (Italy), characterized by approximately $750 \mathrm{~km}$ of coastline subjected to considerable anthropogenic pressures which have caused extensive erosion, a methodology for assessing the coastal erosion risk is strongly required.

The paper describes the definition of a new index-based methodology, which unlike those present in the literature, allows to consider all the factors that come into play, with a standardized and generally valid procedure. The methodology developed, in fact, allows to define two indices of hazard and vulnerability. The hazard index considers all the natural 
processes that contribute to the phenomenon of coastal erosion, such as tides, currents, average sea level rise due to climate change, wave climate and both coastal and river sediment transport. The vulnerability index, on the other hand, includes all those characteristics of the coast that can make it more or less vulnerable to coastal erosion, such as its geological and morphological characteristics (both of the emerged and submerged part), its evolutionary trend, the presence of dune systems, vegetation and coastal and/or port defence works, the subsidence rates and the degree of waterproofing of the coast. The paper also describes the results of the application of the new methodology in Porticello, located in the terminal part of the Strait of Messina (Calabria, Italy).

These results can be combined with the definition of a third index that considers the value of structures, infrastructures, population, cultural heritage, etc. present in the risk area and thus obtain a coastal risk index. From a different combination of the described factors, it will also be possible to evaluate the coastal flooding risk, thus developing a multi-hazard assessment methodology. The results obtained from this methodology can also be plotted on a free access GIS platform, thus offering a useful tool to administrations and stakeholders. For this reason, the methodology described in this paper is of particular relevance and interest in the planning and management of coastal areas.

\section{ACKNOWLEDGEMENT}

This work was supported by the Public Works Department of Calabria Region.

\section{REFERENCES}

[1] Rangel-Buitrago, N., Williams, A. \& Anfuso, G., Hard protection structures as a principal coastal erosion management strategy along the Caribbean coast of Colombia: A chronicle of pitfalls. Ocean and Coastal Management, 156, pp. 58-75, 2018.

[2] Stronkhorst, J., Levering, A., Hendriksen, G., Rangel-Buitrago, N. \& Appelquist, L.R., Regional coastal erosion assessment based on global open access data: A case study for Colombia. Journal of Coastal Conservation, pp. 1-12, 2018.

[3] Komar, P.D., Coastal erosion-underlying factors and human impacts. Shore and Beach, 68(1), pp. 3-16, 2000.

[4] Barragán, J.M. \& de Andrés, M., Analysis and trends of the world's coastal cities and agglomerations. Ocean and Coastal Management, 114, pp. 11-20, 2015.

[5] Bernatchez, P., Fraser, C., Lefaivre, D. \& Dugas, S., Integrating anthropogenic factors, geomorphological indicators and local knowledge in the analysis of coastal flooding and erosion hazards. Ocean and Coastal Management, 54(8), pp. 621-632, 2011.

[6] Williams, A.T., Rangel-Buitrago, N., Pranzini, E. \& Anfuso, G., The management of coastal erosion. Ocean and Coastal Management, 156, pp. 4-20, 2017.

[7] Günaydın, K. \& Kabdaşlı, M.S., Characteristics of coastal erosion geometry under regular and irregular waves. Ocean Engineering, 30(13), pp. 1579-1593, 2003.

[8] Barbaro, G., Foti, G. \& Malara, G., Set-up due to random waves. Transactions of the Royal Institution of Naval Architects Part A: International Journal of Maritime Engineering, 155(PART A3), 2013.

[9] Bacino, G.L., Dragani, W.C. \& Codignotto, J.O., Changes in wave climate and its impact on the coastal erosion in Samborombón Bay, Río de la Plata estuary, Argentina. Estuarine, Coastal and Shelf Science, 219, pp. 71-80, 2019.

[10] Wang, J., You, Z.J. \& Liang, B., Laboratory investigation of coastal beach erosion processes under storm waves of slowly varying height. Marine Geology, 430, article number 106321, 2020. 
[11] Walling, D.E., Human impact on land-ocean sediment transfer by the world's rivers. Geomorphology, 79(3-4), pp. 192-216, 2006.

[12] Barbaro, G., Foti, G., Mandaglio, G., Mandaglio, M. \& Sicilia, C.L., Estimate of sediment transport capacity in the basin of the Fiumara Annunziata (RC). Rendiconti Online Società Geologica Italiana, 21(1), pp. 696-697, 2012.

[13] Barbaro, G., Foti, G., Sicilia, C.L. \& Malara, G., A formula for the calculation of the longshore sediment transport including spectral effects. Journal of Coastal Research, 30, pp. 961-966, 2014.

[14] Barbaro, G., Bombino, G., Foti, G., Borrello, M.M. \& Puntorieri, P., Shoreline evolution near river mouth: Case study of Petrace River (Calabria, Italy). Regional Studies in Marine Science, 29, 100619, 2019.

[15] Foti, G., Barbaro, G., Bombino, G., Fiamma, V., Puntorieri, P., Minniti, F. \& Pezzimenti, C., Shoreline changes near river mouth: Case study of Sant'Agata River (Reggio Calabria, Italy). European Journal of Remote Sensing, 52(4), pp. 102-112, 2019.

[16] Marchesiello, P., Nguyen, N.M., Gratiot, N., Loisel, H., Anthony, E.J., Dinh, C.S., Nguyen, T., Almar, R. \& Kestenare, E., Erosion of the coastal Mekong delta: Assessing natural against man induced processes. Continental Shelf Research, 181, pp. 72-89, 2019.

[17] Valderrama-Landeros, L. \& Flores-de-Santiago, F., Assessing coastal erosion and accretion trends along two contrasting subtropical rivers based on remote sensing data. Ocean and Coastal Management, 169, pp. 58-67, 2019.

[18] Andredaki, M., Georgoulas, A., Hrissanthou, V. \& Kotsovinos, N., Assessment of reservoir sedimentation effect on coastal erosion in the case of Nestos River, Greece. International Journal of Sediment Research, 29(1), pp. 34-48, 2014.

[19] Zema, D.A., Bombino, G., Boix-Fayos, C., Tamburino, V., Zimbone, S.M. \& Fortugno, D., Evaluation and modeling of scouring and sedimentation around check dams in a Mediterranean torrent in Calabria, Italy. Journal of Soil and Water Conservation, 69(4), pp. 316-329, 2014.

[20] Fortugno, D., Boix-Fayos, C., Bombino, G., Denisi, P., Quinonero Rubio, J.M., Tamburino, V. \& Zema, D.A., Adjustments in channel morphology due to land-use changes and check dam installation in mountain torrents of Calabria (southern Italy). Earth Surface Processes and Landforms, 42(14), pp. 2469-2483, 2017.

[21] Versaci, R., Minniti, F., Foti, G., Canale, C. \& Barillà, G.C., River anthropization, case studies in Reggio Calabria (Italy). WIT Transactions on Ecology and the Environment, vol. 217, WIT Press: Southampton and Boston, pp. 903-912, 2018.

[22] Foti, G., Barbaro, G., Manti, A., Foti, P., La Torre, A., Geria, P.F., Puntorieri P. \& Tramontana, N., A methodology to evaluate the effects of river sediment withdrawal: The case study of the Amendolea River in southern Italy. Aquatic Ecosystem Health and Management, 23(4), pp. 465-473, 2020.

[23] Nguyen, Q.H. \& Takewaka, S., Land subsidence and its effects on coastal erosion in the Nam Dinh Coast (Vietnam). Continental Shelf Research, 207, 104227, 2020.

[24] Sarma, K.G.S., Siltation and coastal erosion at shoreline harbours. Procedia Engineering, 116, pp. 12-19, 2015.

[25] Prumm, M. \& Iglesias, G., Impacts of port development on estuarine morphodynamics: Ribadeo (Spain). Ocean and Coastal Management, 130, pp. 58-72, 2016. 
[26] Miduri, M., Foti, G. \& Puntorieri, P., Impact generated by Marina of Badolato (Italy) on adjacent coast. Proceeding of the 13th International Congress on Coastal and Marine Sciences, Engineering, Management and Conservation MEDCOAST, Mellieha, Malta, 2, pp. 935-945, 2017.

[27] Fiori, E., Comellas, A., Molini, L., Rebora, N., Siccardi, F., Gochis, D.J., Tanelli, S. \& Parodi, A., Analysis and hindcast simulations of an extreme rainfall event in the Mediterranean area: The Genoa 2011 case. Atmospheric Research, 138, pp. 13-29, 2014.

[28] Boudet, L., Sabatier, F. \& Radakovitch, O., Modelling of sediment transport pattern in the mouth of the Rhone delta: Role of storm and flood events. Estuarine, Coastal and Shelf Science, 198, pp. 568-582, 2017.

[29] Barbaro, G., Foti, G., Nucera, A., Barillà, G.C., Canale, C., Puntorieri, P. \& Minniti, F., Risk mapping of coastal flooding areas. Case studies: Scilla and Monasterace (Italy). International Journal of Safety and Security Engineering, 10(1), pp. 59-67, 2020.

[30] Barbaro, G., Petrucci, O., Canale, C., Foti, G., Mancuso, P. \& Puntorieri, P., Contemporaneity of floods and storms. A case study of Metropolitan Area of Reggio Calabria in Southern Italy. Prooceedings of New Metropolitan Perspectives (NMP) (Reggio Calabria, Italy), Smart Innovation, Systems and Technologies, 101, pp. 614620, 2019.

[31] Canale, C., Barbaro, G., Petrucci, O., Fiamma, V., Foti, G., Barillà, G.C., Puntorieri, P., Minniti, F. \& Bruzzaniti, L., Analysis of floods and storms: Concurrent conditions. Italian Journal of Engineering, Geology and Environment, 1, pp. 23-29, 2020.

[32] Canale, C., Barbaro, G., Foti, G., Petrucci, O., Besio, G. \& Barillà G.C., Bruzzano river mouth damage due to meteorological events. International Journal of River Basin Management, 2021.

[33] Yang, Z., Wang, T., Voisin, N. \& Copping, A., Estuarine response to river flow and sea-level rise under future climate change and human development. Estuarine, Coastal and Shelf Science, 156, pp. 19-30, 2015.

[34] Toimil, A., Camus, P., Losada, I.J., Le Cozannet, G., Nicholls, R.J., Idier, D. \& Maspataud, A., Climate change-driven coastal erosion modelling in temperate sandy beaches: Methods and uncertainty treatment. Earth-Science Reviews, 202, 103110, 2020.

[35] Maiti, S. \& Bhattacharya, A.K., Shoreline change analysis and its application to prediction: A remote sensing and statistics based approach. Marine Geology, 257(14), pp. 11-23, 2009.

[36] van Rijn, L.C., Coastal erosion and control. Ocean and Coastal Management, 54(12), pp. 867-887, 2011.

[37] Pikelj, K., Ružić, I., Ilić, S., James, M.R. \& Kordić, B., Implementing an efficient beach erosion monitoring system for coastal management in Croatia. Ocean and Coastal Management, 156, pp. 223-238, 2018.

[38] Barbaro, G., Fiamma, V., Barrile, V., Foti, G. \& Ielo, G., Analysis of the shoreline changes of Reggio Calabria (Italy). International Journal of Civil Engineering and Technology, 8(10), pp. 1777-1791, 2017.

[39] Jaranovic, B., Trindade, J., Ribeiro, J. \& Silva, A., Using a coastal storm hazard index to assess storm impacts in Lisbon. International Journal of Safety and Security Engineering, 7(2), pp. 221-233, 2017. 
[40] Ramieri, E., Hartley, A., Barbanti, A., Santos, F.D., Gomes, A., Hilden, M., Laihonen, P., Marinova, N. \& Santini, M., Methods for assessing coastal vulnerability to climate change. ETC CCA Technical Paper, 1, pp. 1-93, 2011.

[41] Torresan, S., Critto, A., Rizzi, J. \& Marcomini, A., Assessment of coastal vulnerability to climate change hazards at the regional scale: The case study of the North Adriatic Sea. Natural Hazards and Earth System Sciences, 12(7), pp. 2347-2368, 2012.

[42] Narra, P., Coelho, C., Sancho, F. \& Palalane, J., CERA: An open-source tool for coastal erosion risk assessment. Ocean and Coastal Management, 142, pp. 1-14, 2017.

[43] Satta, A., Puddu, M., Venturini, S. \& Giupponi, C., Assessment of coastal risks to climate change related impacts at regional scale: The case of Mediterranean region. International Journal of Disaster Risk Reduction, 24, pp. 284-296, 2017.

[44] Foti, G. \& Sicilia, C.L., Analysis, evaluation and innovative methodologies to prevent coastal erosion. WIT Transactions on Ecology and the Environment, vol. 169, WIT Press: Southampton and Boston, pp. 219-230, 2013.

[45] Barbaro, G., Master plan of solutions to mitigate the risk of coastal erosion in Calabria (Italy): A case study. Ocean and Coastal Management, 132, pp. 24-35, 2016.

[46] Mavromatidi, A., Briche, E. \& Claeys, C., Mapping and analyzing socioenvironmental vulnerability to coastal hazards induced by climate change: An application to coastal Mediterranean cities in France. Cities, 72, pp. 189-200, 2018.

[47] Mucerino, L., Albarella, M., Carpi, L., Besio, G., Benedetti, A., Corradi, N., Firpo, M. \& Ferrari, M., Coastal exposure assessment on Bonassola Bay. Ocean and Coastal Management, 167, pp. 20-31, 2019.

[48] McLaughlin, S. \& Cooper, J.A.G., A multi-scale coastal vulnerability index: A tool for coastal managers? Environmental Hazards, 9(3), pp. 233-248, 2010.

[49] Viavattene, C., Jiménez, J.A., Ferreira, O., Priest, S., Owen, D. \& McCall, R., Finding coastal hotspots of risk at the regional scale: The Coastal Risk Assessment Framework. Coastal Engineering, 2017.

[50] Satta, A., Snoussi, M., Puddu, M., Flayou, L. \& Hoult, R., An index-based method to assess risks of climate-related hazards in coastal zones: The case of Tetouan. Estuarine, Coastal and Shelf Science, 175, pp. 93-105, 2016.

[51] Pantusa, D., D’Alessandro, F., Riefolo, L., Principato, F. \& Tomasicchio, G.R., Application of a coastal vulnerability index: A case study along the Apulian Coastline, Italy. Water, 10(9), 2018.

[52] Kantamaneni, K., Phillips, M., Thomas, T. \& Jenkins, R., Assessing coastal vulnerability: Development of a combined physical and economic index. Ocean and Coastal Management, 158, pp. 164-175, 2018.

[53] Anfuso, G. \& Del Pozo, J.A.M., Assessment of coastal vulnerability through the use of GIS tools in South Sicily (Italy). Environmental Management, 43(3), pp. 533-545, 2009.

[54] Pendleton, E.A., Thieler, E.R. \& Williams, S.J., Coastal vulnerability assessment of Cape Hatteras National Seashore (CAHA) to sea-level rise. US Geological Survey Open-File Report, 1064, 2004.

[55] Davies, J.L., A morphogenic approach to world shorelines. Zeitschrift für Geomorphologie, pp. 127-142, 1964.

[56] Boccotti, P., Wave Mechanics for Ocean Engineering, Elsevier, 2000.

[57] Stockdon, H.F., Holman, R.A., Howd, P.A. \& Sallenger A.H.J., Empirical parameterization of setup, swash, and runup. Coastal Engineering, 53(7), pp. 573-588, 2006. 
[58] Tomasicchio, G.R., D’Alessandro, F., Barbaro, G. \& Malara, G., General longshore transport model. Coastal Engineering, 71, pp. 28-36, 2013.

[59] Gavrilovic, S., Méthode de la classification des bassins torrentiels et équations nouvelles pour le calcul des hautes eaux et du débit solide. Vadoprivreda, Belgrado, Serbia, 1959. (In French.)

[60] Silva, S.F., Martinho, M., Capitão, R., Reis, T., Fortes, C.J., \& Ferreira, J.C., An indexbased method for coastal-flood risk assessment in low-lying areas (Costa de Caparica, Portugal). Ocean and Coastal Management, 144, pp. 90-104, 2017. 